\title{
How can molecular ecology contribute to forest restoration?
}

\author{
Marcos Vinícius Bohrer Monteiro Siqueira ${ }^{*}$, Patricia Sanae Sujii², Miklos Bajay ${ }^{3}$, \\ Carolina Grando², Kaiser Schwarcz ${ }^{2}$, Camila Macrini' ${ }^{1}$, Maria Imaculada Zucchi ${ }^{1}$.
}

\begin{abstract}
The advance of scientific knowledge in various areas of molecular ecology has allowed the adoption of new strategies, particularly in forest restoration. The fusion of multidisciplinary areas and the implementation of management methodologies in order to get better results in forest restoration are current realities. In order to review the main ideas about the role of molecular techniques in the service of ecology restoration, this paper outlines how forest recovery can benefit from genetic and genomic plant population studies. The next challenges in conservation genetics can be brought by the quest for more efficient forest restorations from the point of view of biodiversity as well as the ecological dynamics as a whole. It is believed that in the coming years we will observe integrated strategies in molecular ecology with specific methodologies for restoration in tropical forests.
\end{abstract}

Keywords: forest restoration, conservation genetics, molecular ecology, population genetics.

\section{Como pode ecologia molecular contribuir para a restauração florestal?}

\section{RESUMO}

O avanço do conhecimento científico nas várias áreas da ecologia molecular tem permitido que novas estratégias sejam adotadas, nomeadamente, na disciplina de restauração florestal. A fusão de áreas multidisciplinares e a implementação de metodologias no sentido de buscar melhores resultados na restauração florestal são realidades atuais. Objetivando rever as principais ideias sobre o papel das técnicas moleculares a serviço da restauração ecológica, o presente trabalho traça como a recuperação das florestas pode ser beneficiada pelos estudos de genética e de genômica populacional de plantas. Os próximos desafios na genética da conservação podem ser traduzidos por desenvolvimento de projetos de restauração mais eficientes, seja do ponto de vista da biodiversidade como da dinâmica ecológica. Acredita-se que nos próximos anos observemos estratégias integradas de ecologia molecular com metodologias específicas para restauração de florestas tropicais.

Palavras-chave: restauração florestal, genética da conservação, ecologia molecular, genética de populações.

\footnotetext{
*Author for correspondence.

1,*Agência Paulista de Tecnologia dos Agronegócio. Polo Regional Centro Sul, Rodovia SP 127, km 30, Bairro: Vila Fátima, Caixa Postal: 28 - CEP: 13400-970, Piracicaba/SP - Brasil, mvbsiqueira@gmail.com

${ }^{2}$ Universidade Estadual de Campinas, ${ }^{3}$ Escola Superior de Agricultura Luiz de Queiroz/USP
} 


\section{INTRODUCTION}

The new Brazilian forest code was approved by the national congress in 2011, when it had high repercussion and occupied considerable media time. The new legislation was sanctioned with several vetoes by the president and new discussion and votes in congress brought up a delicate subject. In this great debate about the Brazilian forests, we understood that policies should be reviewed, giving goals and duties to reach sustainability and preservation of our natural resources. Moreover, such decisions brought to the population the concern of how to deal with resources and which goals should be targeted. For many, the "Rio + 20" World Forum in 2012, brought a few concrete actions of forest conservation, but left profound environmental questions to second plan to many governments.

The country has a high biological richness (Giulietti et al., 2005; Vitule, 2012), which has been unsustainably exploited over the years, especially with the development of Brazilian agriculture. The legal reserves, water springs zones and other permanent preservation areas bring benefits to all sectors, including agribusiness. According to Galdolfi (2011), discussion of this topic is vast and complex, and legal reserves are a strategic and invaluable tool for the economic, social, scientific and technological development of Brazil.

The restoration of areas that have been degraded by human activity is essential for the sustainability of the environment and allows for the connection of forest patches. Thus, it becomes necessary to map priority areas for restoration and conservation, aiming to establish a policy that reconciles agroecology productivity and environment conservation (Rogalski et al, 2003; Joly et al, 2010).

With the increasing demand for recovery and management of these areas, it is essential that theoretical concepts about the composition, structure and functioning of tropical ecosystems are undertaken for the construction of appropriate technologies for these actions. Besides the concern for forest restoration, it is also important to recover the complex networks of inter and intraspecific interactions and to make possible the long-term conservation of habitats and organisms (Koskela et al., 2003).

The fusion of concepts and practices of population ecology and population genetics is essential to guide the actions to be undertaken in the field of biology conservation (Kageyama \& Gandara, 1998). However, despite the broad theoretical basis for population genetics studies found in the literature (Allendorf \& Luikart, 2006), the application to issues such as conservation and management of natural populations disturbed by anthropogenic factors is still recent (Lowe et al., 2005), especially in Brazil (Kageyama \& Gandara, 2004). More incipient are the studies on restoration ecology to assist the definition of more efficient strategies for reforestation of degraded areas (Engel \& Parrotta, 2001; Leopold et al., 2001), especially as regards the restoration of genetic diversity of tree populations (Rodrigues et al., 2009). The use of molecular markers in population genetics studies allowed the development of a new way of analyzing population patterns and relationships between individuals of the same species. The Molecular Ecology is showing up as a study area with several applications, among them, the conservation of species, ecosystems and forest restoration. The purpose of this article is to underline how Molecular Ecology can be applied to forest restoration and what is the return of these investments in the quality of forest restoration projects.

\section{Molecular biology in the service of forest restoration}

Molecular markers are one of the main tools in Molecular Ecology studies. They are landmarks in the chromosome, where it is possible to verify the genetic polymorphism at the DNA level (Grattapaglia \& Ferreira, 1998). These markers are used to understand the population's genetic diversity and structure, and also to determine the reproductive system of these species, to test hypotheses of migration patterns, and to understand how the processes of gene flow and genetic drift are affected due to landscape fragmentation (Heywood \& Iriondo, 2003; González-Martínez et al., 2006).

In modern projects of forest restoration it is essential to take into account the richness of species and their genetic diversity, considering the consequences of the level of genetic diversity located in the target area. Thus, population genetics is critical to the design and implementation of any restoration project. It is directly related to the population's ability to evolve in response to environmental changes and 
to adapt to the current environment in which it is found (Falk et al., 2006).

Genetic effects resulting from habitat loss are important factors to be considered in the study of genetic diversity. Since the anthropic action on forest areas usually reduces the size and number of the populations, the effects of genetic drift over them become more pronounced. Genetic drift is the change in genetic composition of populations as a result of chance. Common consequences of habitat loss and isolation of forest fragments are reduced genetic variability $\left(\mathrm{H}_{\mathrm{e}}\right)$, smaller effective population size $\left(\mathrm{N}_{\mathrm{e}}\right)$, and the possible increase of inbreeding ( $\left.\mathrm{F}_{\mathrm{IS}}\right)$ among loci (Hartl \& Clark, 1997). These genetic effects can have serious consequences for plant populations, such as reduced reproductive success and ongoing population reduction (Nason \& Hamrick, 1997).

Another important issue to be discussed is the influence of deforestation on the genetic structure of populations, i.e., how the populations of each species are grouped considering their genotypes. Knowledge of the population genetic structure is essential to conservationists so that they can make changes in magnitude and desired direction. The replacement of the original vegetation by an anthropogenic landscape, in most cases by pasture or crops for agriculture, negatively influences the ability of species dispersion and consequently gene flow $(\mathrm{Nm})$ between populations. In this scenario, it is commonly observed the increase of genetic structure (Hamrick, 2004; Haag et al. 2010), usually calculated by the estimator $\Theta$ (Weir \& Cockerham, 1984). From the viewpoint of metapopulation, reduced gene flow between demes increases the effect of stochastic events such as genetic drift, which may radically reduce the persistence time of species (Hanski, 1991). Forest restoration is an important tool to minimize the isolation of populations. If the restored areas work effectively as a stopping point for pollinators and seed dispersers, gene flow can be restored and the effects of genetic drift can be slowed, i.e., reducing the loss of genetic diversity (Young et al., 1996).

The current restoration model accepted by the scientific community has an emphasis on the recovery of ecological processes that lead to the development of plant communities (Brancalion et al., 2009). However, there is great concern about the diversity of species, but little attention is given to intraspecific diversity. Generally, seedlings introduced in reforestation areas have low genetic diversity, because they come from few seed matrices, which can generate the same negative consequences of fragmentation (Brancalion et al., 2009). Recent studies indicate that it is of vital importance to select source populations with high genetic diversity and collect a random sample of seeds, respecting the minimum number of trees (Kageyama \& Gandara, 2000). For an effective size of at least 50 individuals in the restored population, it is suggested to collect seeds from at least 12 matrices (Brancalion et al., 2009)

Even if forest restoration has been done with care to maintain genetic diversity, it is also important to note if this diversity can be maintained in the long term, since there is a downward trend over the generations. Inbreeding and fine-scale structure, on the other hand, are the most immediate indicators of the impact of the reduction in population and the restriction of seed dispersal (Lowe 2005).

The reforestation of degraded areas is critical when considering the current state of fragmentation of native ecosystems in the country. Reed and Frankham (2003) found a significant correlation between genetic variation and the likelihood of long-term survival of a population and that adaptability is reduced in small populations due to genetic drift and inbreeding depression. Considering the case of the Atlantic Rain Forest, which was reduced approximately to $11.7 \%$ of the original area of the biome in fragment areas (Ribeiro et al., 2009), forest restoration based on studies of population genetics can be seen as another tool for conservation.

\section{Next challenges}

Since the 1980's it is understood that biodiversity loss has been caused by man, and currently most of the scientific community agrees that the main challenge of this century is to prevent this loss of diversity at different levels: genes, species and ecosystems (Rands et al., 2010). Understanding "what, where and how to save" has gained priority in conservation biology, especially in species that inhabit major threatened hotspots (Brandon et al., 2005; Scheffers et al., 2012). Therefore, the conservation of species relies heavily on the concept of endemism, as well as the number of existing species. These decisions are best viewed using biogeographic methods that aim to understand critically the patterns of spatial distribution of organisms and respond to how these patterns were formed (Carvalho, 2009). 
The rich native biodiversity of the state of São Paulo, Brazil, is threatened by changes in vegetation cover and effects of habitat fragmentation (Tabarelli et al., 2005; Brancalion et al., 2009). The Virtual Institute of Biodiversity BIOTA-FAPESP is a research program that focuses on conservation of biomes and one of its missions is to identify priority areas for forest restoration, with the goal of connecting forest fragments of native vegetation and select areas to create new conservation units (Joly et al., 2010). Integrated into this program, our group develops a contribution to the project entitled "Conservation Biology of native Atlantic Rainforest with phytotherapic potential: A genetic approach to forest restoration." One objective of this research is to understand the main differences between the remaining areas and areas undergoing restoration under the genetic point of view of some tree species using molecular markers to evaluate these differences.

With the development of microsatellite markers for forest species in this project, diversity and population genetic structure may be assessed. Furthermore, the use of a large number of samples and the application of markers such as AFLP, SNP, among others, in order to obtain a larger number of markers will, in an innovative way, compare the genomics of populations from degraded areas and forest remnants. The current project is expected to evaluate a possible methodology for enrichment of genetic diversity in previously reforested areas and contribute strongly to the field of molecular ecology applied to forest restoration.

\section{REFERENCES}

ALLENDORF, F.W.; LUIKART, G. Conservation and the genetics of populations. Wiley-Blackwell Editor, 1 edition, 664p. 1999.

BRANCALION, P.H.S.; GANDOLFI, S.; RODRIGUES, R.R. Incorporação do conceito da diversidade genética na restauração ecológica. In: Rodrigues, R.R.; Brancalion, P.H.S.; Isernhagen, I. (Org.). Pacto para a restauração da Mata Atlântica: referencial dos conceitos e ações de restauração florestal. 1 ed. São Paulo: Instituto BioAtlântica, v. 1, p. 37-54. 2009.
CARVALHO, C.J.B. Padrões de endemismos e a conservação da biodiversidade. Megadiversidade, v. 5, n. 1-2, p. 77-86. 2009.

CHOI, Y.D. Theories for ecological restoration in changing environment: Toward 'futuristic' restoration. Ecological Research v. 19, n. 1, p. 75-81, 2004.

ENGEL, V.L.; PARROTTA, J.A. An evaluation of direct seeding for reforestation of degraded land in central Sao Paulo state, Brazil. Forest Ecology and Management, v. 152, n. 1-3, p. 169-181, 2001.

FALK, D.A.; PALMER, M.A.; ZEDLER, J.B. Foundations in Restoration Ecology. Island Press. Washington, D.C: Island Press. 378p. 2006.

GALDOLFI Impactos das alterações no código florestal. In: IV Simpósio de Restauração Ecológica - Desafios atuais e futuros. Anais...São Paulo. p. 21-25, 2011.

GIULIETTI, A.M.; HARLEY, R.M.; QUEIROZ, L.P.; WANDERLEY, M.G.L.; BERG, C.V.D. Biodiversity and Conservation of Plants in Brazil. Conservation Biology v. 19, n. 3, p. 632-639. 2005.

HAMRICK, D.L. Response of trees to global environmental changes. Forest ecology and Management v. 197, n. 1-3, p. 323-335. 2004.

HAAG, T.; SANTOS, A. S.; SANA, D. A.; MORATO, R. G.; CULLEN JR, L.; CRAWSHAW JR, P. G.; ANGELO, C. DE; BITETTI, M. S. DI; SALZANO, F. M.; EIZIRIK, E. The elect of habitat fragmentation on the genetic structure of a top predator: loss of diversity and high diferentiation among remnant populations of atlantic forest jaguars (Panthera onca). Molecular Ecology v. 19, n. 22, p. 4906-4921, 2010.

HANSKI, I.; GILPIN, M.E. Metapopulation dynamics: empirical and theoretical investigations. New York: Academic press. 1991.

HART, D.L.; CLARK, A.G. Principles of population genetics. 3rd edition. Sunderland (MA): Sinauer Associates. 1997. 
HEYWOOD, V.H.; IRIONDO, J.M. Plant conservation: old problems, new perspectives. Biological Conservation, v. 113, n. 3, p. 321-335. 2003.

HOLL, K.D.; AIDE, T.M. When and where to actively restore ecosystems? Forest Ecology and Management v. 261, n. 10, p. 1558-1563, 2011.

JOLY, C.A.; RODRIGUES, R.R.; METZGER, J.P. HADDAD, C.F.B.; VERDADE, L.M.; OLIVEIRA, M.C.; BOLZANI, V.S. Biodiversity Conservation Research, Training, and Policy in São Paulo. Science v. 328, n. 5984, p. 1358-1359. 2010.

JOHNSON, J.B.; PEAT, S.M.; ADAM, B.J. Where's the ecology in molecular ecology? Oikos v. 118, n. 11, p. 1601-1609. 2009.

JONES, T.A. The Restoration Gene Pool Concept: Beyond the Native Versus Non-Native Debate. Restoration Ecology v. 11, n. 3, p. 281-290. 2003.

KAGEYAMA, P.Y.; GANDARA, F.B. Recuperação de áreas ciliares. In: Rodrigues, R.R.; Leitão Filho, H.F. (Eds.) Matas ciliares: Conservação e recuperação. São Paulo: Universidade de São Paulo, p.249-269. 2004.

Resultados dos programas de restauração com espécies arbóreas nativas do convênio ESALQ/USP e CESP. In: Galvão, A.P.M.; Porfírio-Da-Silva, W. (Eds) Restauração Florestal - Fundamentos e Estudos de Caso, 2005.

KAGEYAMA, P.Y.; SEBBENN, A.M.; RIBAS, L.A.; GANDARA, F.B.; CASTELLEN, M.; PERECIN, M.B.; VENCOVSKY, R. Diversidade genética em espécies tropicais de diferentes estágios sucessionais por marcadores genéticos. Scientia Forestalis v. 64, p. 93-107, 2003.

KAGEYAMA, P.Y.; GANDARA, F.B. Dinâmica de populações de espécies arbóreas: implicações para o manejo e a conservação. In: III Simpósio de ecossistemas da costa brasileira. Anais. Academia de Ciências do Estado de São Paulo, p.115-125. 1993.

KOBAYASHI, S. Landscape rehabilitation of degraded tropical forest ecosystems Case study of the CIFOR/Japan project in Indonesia and Peru. Forest Ecology and Management v. 201, n. 1, p. 13-22, 2004.

KOSKELA, J.; SAJISE, P.; HONG, L.T. Forest rehabilitation and forest genetic diversity management implications and research needs. In RAP Publication, No.14., p. 229-244. 2003.

LEOPOLD, A. C.; ANDRUS, R.; FINKELDEY, A.; KNOWLES, D. Attempting restoration of wet tropicalforests in costa rica. Forest Ecology Management, v. 142, n. 1-3, p. 243-249. 2001.

LOWE, A.J.; BOSHIER, D.; WARD, M.; BACLES, C.F.E; NAVARRO, C. Genetic resource impacts of habitat loss and degradation; reconciling empirical evidence and predicted theory for neotropical trees. Heredity, v. 95, n. 4, p. 255-273. 2005.

MARTINS, K.; RIBAS, L.A.; MORENO, M.A.; WADT, L.H.O. Conseqüências genéticas da regeneração natural de espécies arbóreas em área antrópica, AC, Brasil. Acta Botanica Brasilica, v. 22, n. 3, p. 897-904. 2008.

NASON, J.D.; HAMRICK, J.L. Reproductive and genetic consequences of forest fragmentation: two case studies of Neotropical canopy trees. Journal of Heredity, v. 88, n. 4, p. 264-276. 1997.

PALMER, M.A.; BERNHARDT, E.S. Scientific pathways to effective river restoration. Water Resources Research, v. 42, n. 3, p. W03507, 2006.

RANDS, M.R.W.; ADAMS, W.M.; BENNUN, L.; BUTCHART, S.H.M.; CLEMENTS, A.; COOMES, D.; ENTWISTLE, A.; HODGE, I.; KAPOS, V.; SCHARLEMANN, J.P.W.; SUTHERLAND, W.J.; VIRA, B. Biodiversity Conservation: Challenges Beyond. Science v. 329, n. 5997, p. 1298-1303. 2010.

REED, D.H.; FRANKHAM, R. Correlation between fitness and genetic diversity. Conservation Biology, v. 17, p. 23-237. 2003.

RIBEIRO, M.C.; METZGER, J.P.; MARTENSEN, A.C.; PONZONI, F.J.; HIROTA, M.M. The Brazilian Atlantic Forest: How much is left, and how is the remaining forest distributed? 
Implications for conservation. Biological Conservation, v. 142, v. 6, p. 1141-1153. 2009.

RODRIGUES, R.R.; GANDOLFI, S.; NAVE, A.G.; ARONSON, J.; BARRETO, T.E.; VIDAL, C.Y.; BRANCALION, P.H.S. Large-scale ecological restoration of high-diversity tropical forests in SE Brazil. Forest Ecology and Management v. 261, n. 10, p. 1605-1613. 2001.

RODRIGUES, R. R.; BRANCALION, P. H. S.; ISERNHAGEN, I. Pacto pela restauração da mata atlântica: Referencial dos conceitos e ações de restauração florestal. São Paulo: LERF/ESALQ, 2009.

ROGALSKI, J. M.; BERKENBROCK, I. S.; REIS, A.; REIS, M. S. Sucessão e manutenção da diversidade biológica e da variabilidade genética: ferramentas básicas para a restauração ambiental. Disponível em: www.sobrade.com.br/eventos/2003/seminario/Tra balhos/025.pdf. Acesso em 02 de março de 2012.

SCHEFFERS, B. R.; JOPPA L. N.; PIMM, S. L.; LAURANCE, W. F. What we know and don't know about Earth's missing biodiversity. Trends in Ecology and Evolution, v. 27, n. 9, p. 501-510. 2012.

SINCLAIR, E.A.; HOBBS, R.J. Sample Size Effects on Estimates of Population Genetic Structure: Implications for Ecological Restoration. Restoration Ecology. V. 17, n. 6, p. 837-844. 2008.

SMITH, S. L.; SHER, A. A.; GRANT, T.A. Genetic Diversity in Restoration Materials and the Impacts of Seed Collection in Colorado's Restoration Plant Production Industry. Restoration Ecology v. 15, n. 3, p. 369-374, 2007.

TABARELLI, M.; PINTO, L. P.; SILVA, J. M. C.; HIROTA, M.; BEDÊ, L. Challenges and Opportunities for Biodiversity Conservation in the Brazilian Atlantic Forest. Conservation Biology v. 19, n. 3, p. 695-700. 2005.

THOMAS, B.R.; MACDONALD, S.E.; HICKS, M.; ADAMS, D.L.; HODGETTS, R.B. Effects of reforestation methods on genetic diversity of lodgepole pine: an assessment using microsatellite and randomly amplified polymorphic DNA markers. Theoretical Applied Genetics v. 98, n. 5, p. 793-801. 1999.

VITULE, J. R.S. Ecology: Preserve Brazil's aquatic biodiversity. Nature v. 485, n. 7398, p. 309. 2012.

WEIR, B.S.; COCKERHAM, C.C. Estimating Fstatistics for the analysis of population structure. Evolution v. 38, n. 6, p. 1358-1370. 1984.

YOUNG, A.; BOYLE, T.; BROWN, T. The population genetic consequences of habitat fragmentation for plants. Tree, v. 11, n. 10, p. 413-418. 1996.
Recebido: 11/03/2013

Received: 03/11/2013

Aprovado: 27/09/2013

Approved: 09/27/2013 